\title{
The Effectiveness of Yoga Therapy on Early Maladaptive Schemas and Emotional Distress of Depressed Women: A Semi Experimental Study
}

\author{
Sahar Saeidi Asl 1 (D), Fatemeh Sadat Robati²* iD
}

1. M.A. of General Psychology, Department of Psychology, Islamic Azad University, Rafsanjan Branch, Rafsanjan, Iran

2. Assistant Professor, Department of Psychology, Islamic Azad University, Rafsanjan Branch, Rafsanjan, Iran

Article Info ABSTRACT

Received: 2020/08/08;

Accepted: 2020/09/08; Published Online: 2020/11/28

\subsection{9/ajnmc.29.2.137}

Original Article Use your device to scan
and read the article online

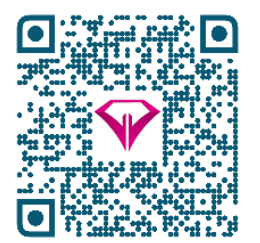

Introduction: Using yoga movements helps depressed women to become aware of and control their minds and emotions. The aim of this study was to investigate the effectiveness of yoga therapy on early maladaptive schemas and emotional distress of depressed women in Tehran.

Methods: This study was a quasi-experimental study with a pre- and post-test design with a control group. The statistical population of the study included all depressed women referring to Omid and Rah-e-Farda counseling centers in the first half of 2019 in Tehran, Iran. The sampling method was available sampling. The sample size was at least 10 based on the type of research that was considered in the experimental research for each group. The sample was 30 subjects who were randomly divided into two groups of experimental (15 people) and control (15 people). The research tools included the Yang Inconsistent Schema Questionnaires (2005) and Toronto's Emotional Disappointment (2005). To analyze the data, mean, standard deviation and covariance analysis were used using SPSS 23. P-value less than 0.05 was considered significant.

Results: In the cut-off and exclusion variables in the pre-test of the intervention group, the mean and standard deviation were $2.85 \pm 21.03$, in the control group $3.50 \pm 16.46$, in the cut-off and exclusion variables in the post-test of the intervention group, the mean and standard deviation was $4.28 \pm 15.28$, in the control group $3.28 \pm 15.28$, in the variable of disturbed restrictions in the pre-test of the intervention group, the mean and standard deviation were $3.72 \pm 12.63$, in the control group $30 \pm 17.803$. In the disturbed constraint variable in the post-test of the intervention group, the mean and standard deviation were $4.43 \pm 17.76$, in the control group was $3.76 \pm 17.90$, and in the emotional malaise variable in the pre-test of the intervention group, the mean and standard deviation of $49.80 . \pm 37.67$, in the control group $52.86 \pm 36.51$, in the variable of disturbed constraints in the post-test of the intervention group, the mean and standard deviation of 13.06. \pm 23.73 , in the control group $33.37 \pm 76.3$, was obtained. The results showed that there was a significant difference between the scores of incompatible schemas, emotional inadequacy and psychological health of the experimental and control group in the post-test stage $(P<0.01)$.

Conclusion: Thus, yoga therapy is an effective treatment for maladaptive schemas, emotional distress, and of depressed women.

Keywords: Depressed women, Early maladaptive schemas, Emotional distress, Yoga therapy

\section{Corresponding Information:}

Fatemeh Sadat Robati, Assistant Professor, Department of Psychology, Islamic Azad University, Rafsanjan Branch, Rafsanjan, Iran. Email: robatyfatmeh@yahoo.com

Copyright $(C 2021$, This is an original open-access article distributed under the terms of the Creative Commons Attribution-noncommercial 4.0 International License which permits copy and redistribution of the material just in noncommercial usages with proper citation.

How to Cite This Article:

Saeidi Asl S, Robati F S. The Effectiveness of Yoga Therapy on Early Maladaptive Schemas and Emotional Distress of Depressed Women: A Semi Experimental Study. Avicenna J Nurs Midwifery Care. 2021; 29 (2) : $137-145$ 
اثربخشى يوگَادرمانى بر طرحوارههاى ناسازگًار اوليه و ناكويى هيجانى زنان افسرده: يك مطالعهُ نيمه تجربى سحر سعيدى اصل (id) '، فاطمه السادات رباطى (id)

$$
\begin{aligned}
& \text { '. . كارشناسى ارشد، كروه روانشناسى، دانشكاه آزاد اسلامى، واحد رفسنجان، رفسنجان، ايران }
\end{aligned}
$$

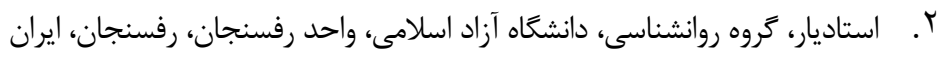

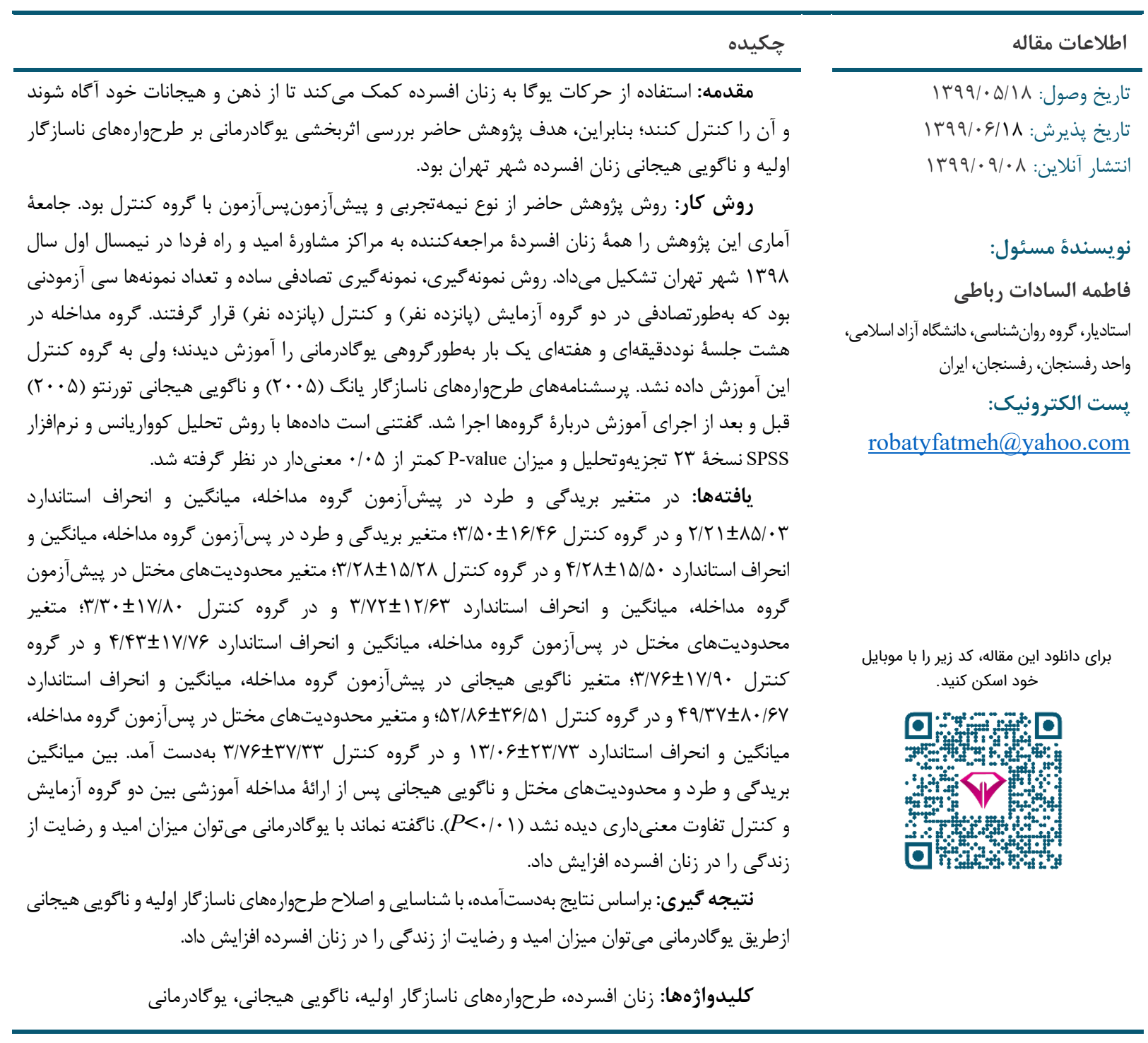

مقدمه

همراه اضطراب و افسردگى، ازجمله احساس بىارزشى يا ناميدى نيز واكنشهايى مانند انكار و خشم و احساس كناه ايجاد مى كند كه از اين طريق بر سلامت عمومى مبتلايان به به

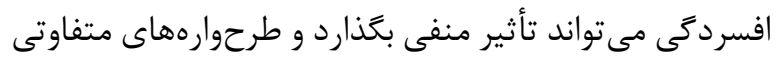

داشته باشد [ب].
زنان مبتلا به افسردحى نهتنها با سلسلهمشكلات جسمى، بلكه با مشكلاتى نظير درماندكى آموختهشده و مشكلات طرحوارهاى و اضطراب بلهنبال تشخيص و درمان و سير داني

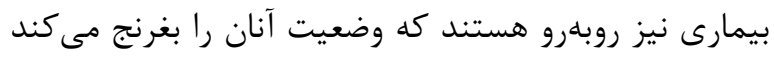

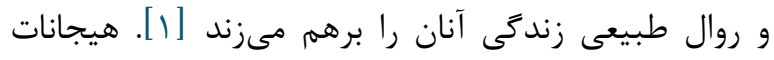


دفاعى ناسازگارانه ارتباط قوى مشاهده مىشود و ناكويى هيجانى مكانيسمى مقابلهاى براى محافظت از خود درمقابل

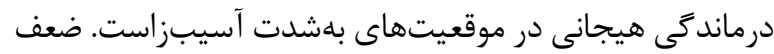

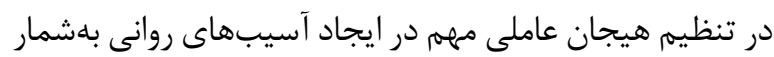

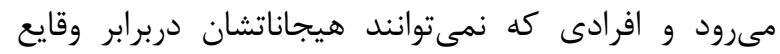
زندگى را بلدرستى مديريت كنند، بيشتر از ديكران دجار

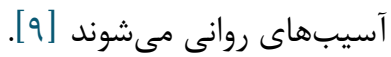

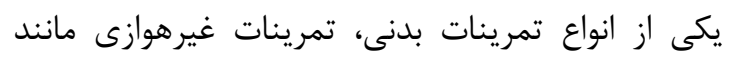
يوكاست كه بهآرامى انجام و به ارتباط جسمى و شنات شناختى در

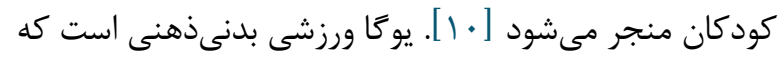

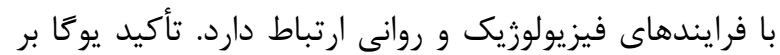
آرامسازى است و تمرينات آن ايستا و يويا انجام مىشوند كه از ورزشهاى معمولى متمايز هستند. يوكا بهطورمنظم باعث إنى

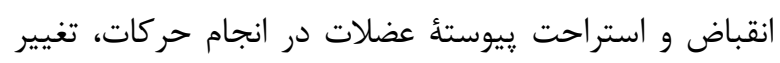
الكَوى تنفسى، تقويت توجه و هوشيارى ذهنى، افزايش سرعت

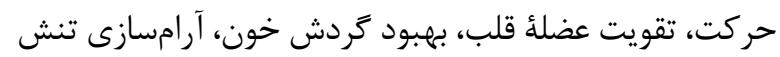

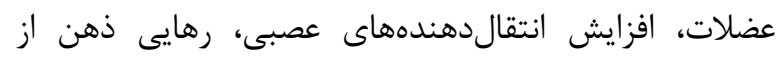
استرس و هيجانات منفى در طول تمرين مىشود. تمرينات

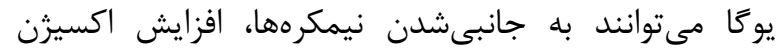

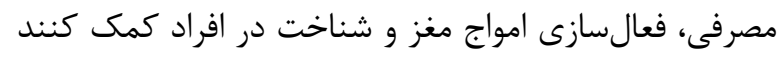

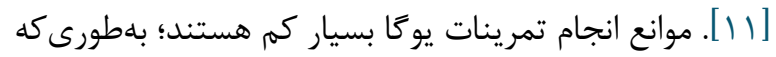
انواع تمرينات آن در هر موقعيتى (خانه يا باشعاه) مىتواند انجام شوند. مطالعات بهخوبى نشان مى دهند كه تمرينات يوكًا

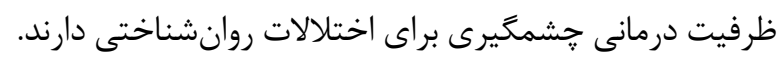

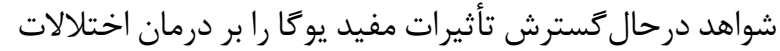
عصب روانيزشكى، مانند افسردىى و ساير اختلالات نشان

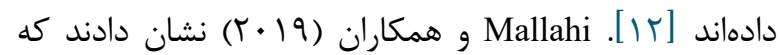

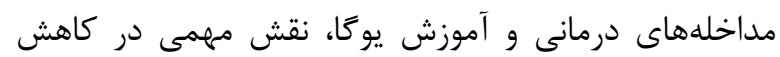

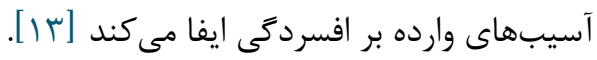

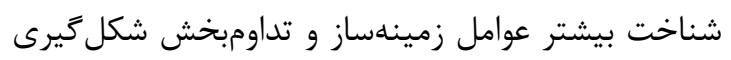
طرحوارههاى ناساز است. اكثر مداخلات درمانى بر ابعاد جسمانى اين آسيبها

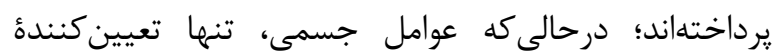

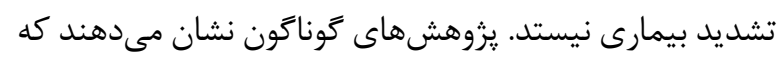

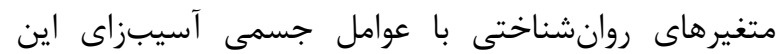
بيمارى در تعامل و زمينهساز آن هستند. باتوجهبه نقائ

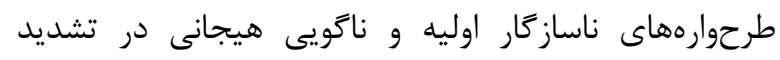

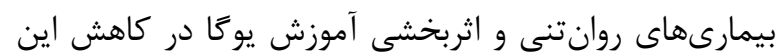

طرحواره مفهومى در روانشناسى شناختى است و اين

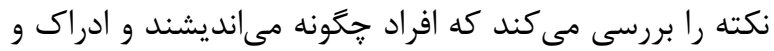

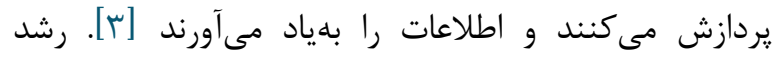

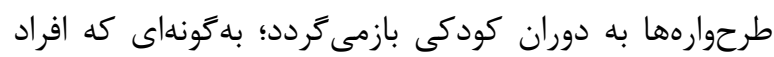
بهدليل تجارب منفى، طرحوارههاى ناسازگار اوليهاى ايجاد مى كنند كه بر شيوه تفكر و احساس و رفتار آنان و ساير ابعاد

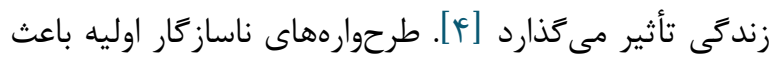
مىشود افراد از اتفاقات زندگى خود تفارد تفاسير متفاوتى داشته

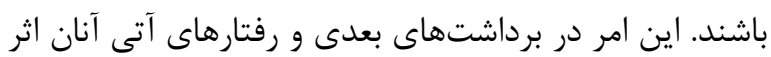

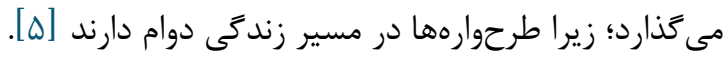

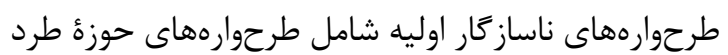
و بريدگى و حوزه خودَردانى و عملكرد مختل است. در حوزه طرد و بريدگى، انتظار اين است كه نيازهاى فرد براى امنيت،

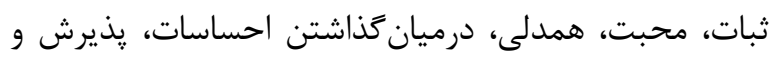

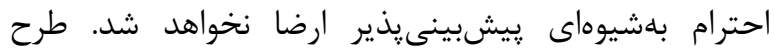

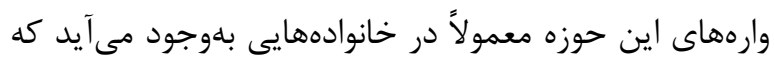

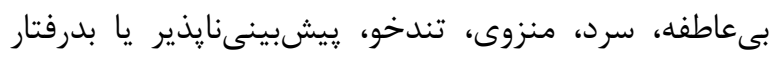

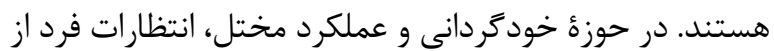
خود و محيطش با توانايىهاى محسوس او براى جدايى، بقا و

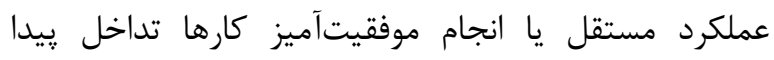

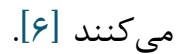
ناتويى هيجانى بهمعناى بى تمايلى به بروز هيجانات است.

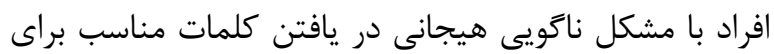
توصيف احساسات و بيان هيجاناتشان ناتواناند و اين مسئله در بسيارى از بيماران روانتنى مشاهده مىشود. درواقع، شكايت اصلى اين بيماران هنكام مراجعه به يز ئشك ناكويى

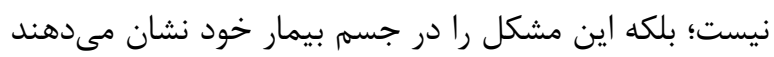
و بلهجاى توصيف احساسات خود، جزئيات را شرح مى دهند. همجنين، اين افراد تمايل دارند درعوض بيان هيجانات، وقايع

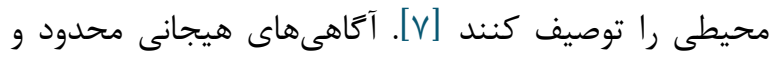
فرايندهاى شناختى معيوب در زمينهُ عواطف افراد مبتلا به

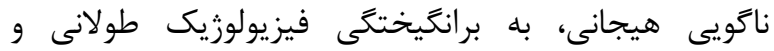

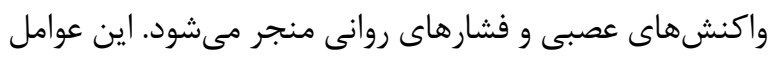

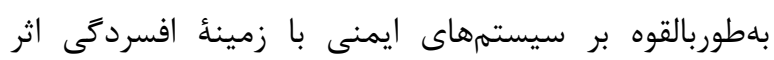
تخريبى مى كذارند [^].] تحقيقات نشان داده است كه بين ناكويى هيجانى و إنى تحمل

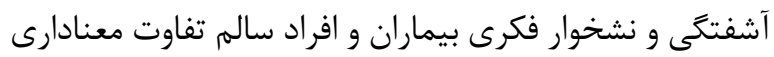
وجود دارد. افزونبراين، بين ناگويى هيجانى و مكانيسمهاى 
يرسشنامة راهبردهاى ناگويى هيجانى تورنتو

(Emotion Regulation Questionnaire)

در اين يزوهش، بهمنظور اندازميرى ناكويى هيجانى از

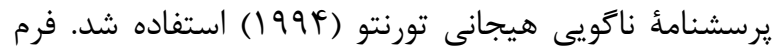

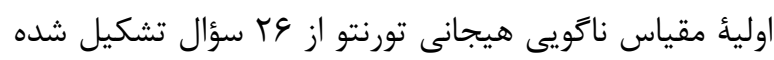

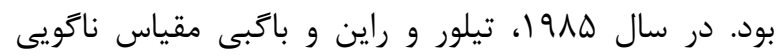

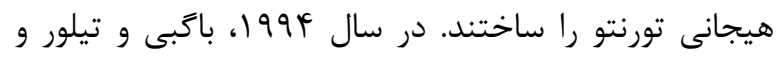

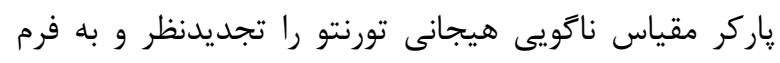

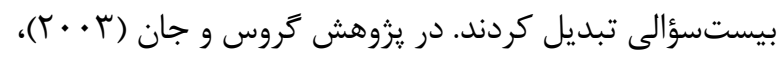

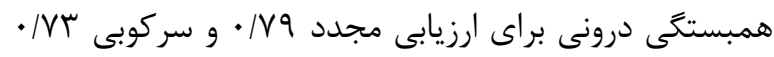

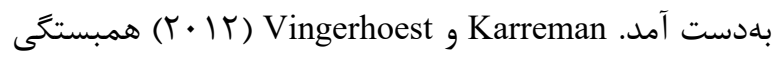

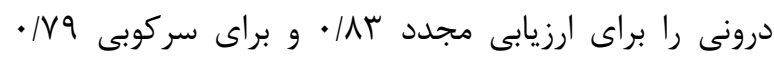

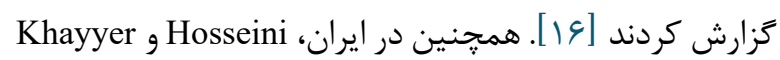

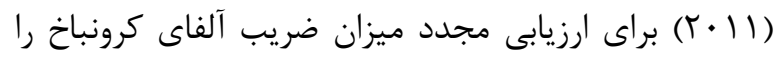

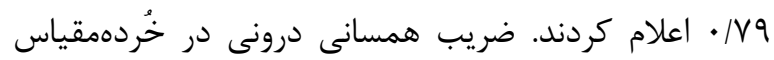

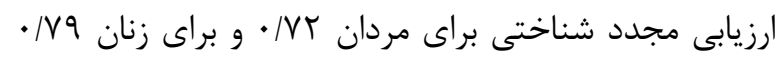

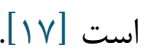

سيس گروه مداخله در مدت هشت هفته و هشت جلسأ

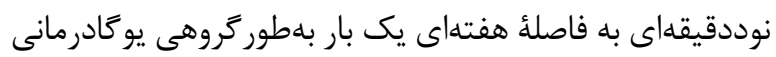

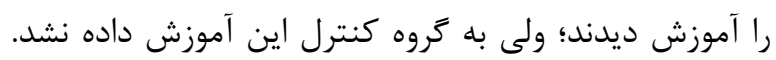

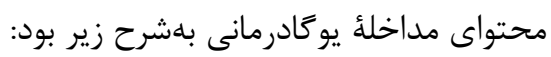

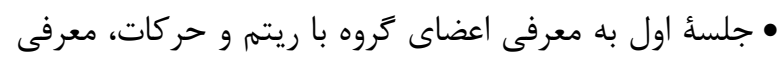

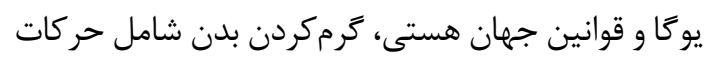

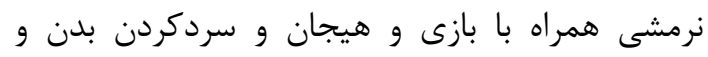

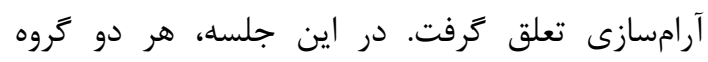

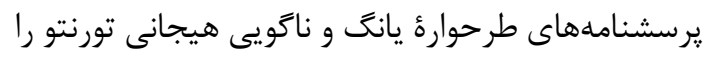
در شروع مطالعه تكميل كردند.

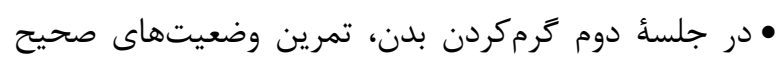

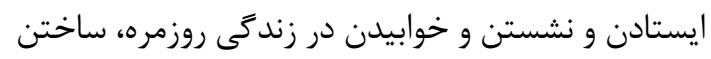

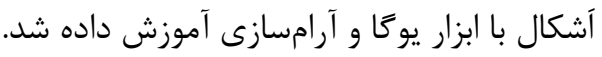

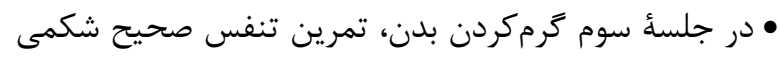

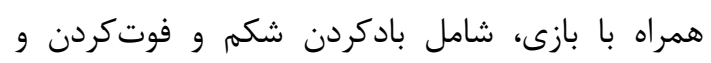
بادكردن بادكنك و آرامسازى انجام شد.

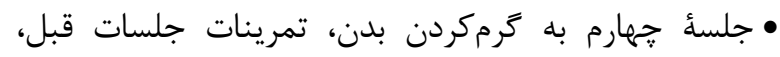

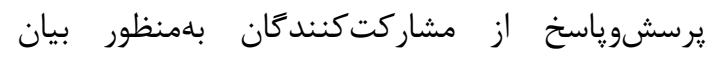
احساسات و علايق آنان و آرامسازى اختصاص يافت. • جلسة ينجمم
مشكلات و بهدليل فقر يزوهشى بارز در اين زمينه در داخل كشور، هدف يزوهش حاضر بررسى اثربخشى يوكادرمانى بر بران بارئ

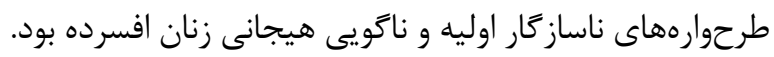

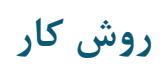

يزوهش حاضر از نوع نيمهتجربى بود كه به روش

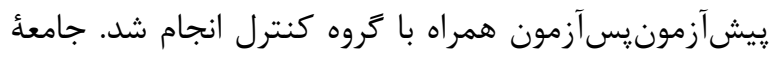

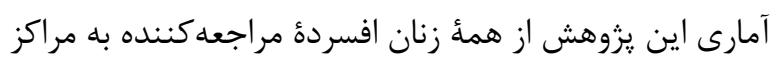

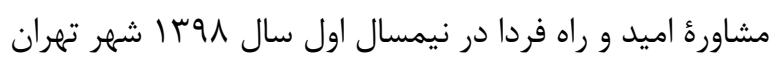
تشكيل مىشد. روش نمونه گيرى، نمونه كيرى تصادفى ساده و

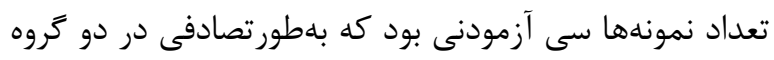

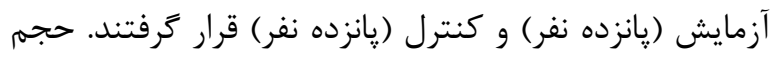

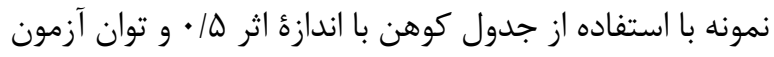

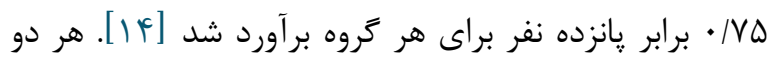

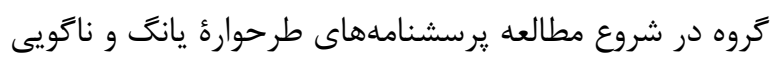
هيجانى تورنتو را تكميل كردند.

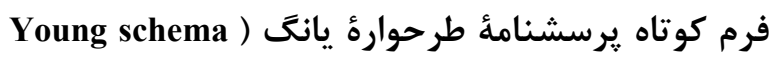

(Questionnaire-Short Form

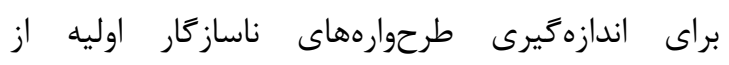

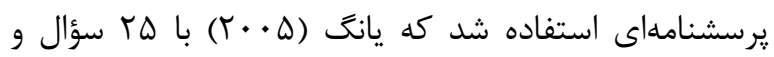

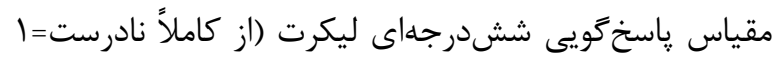

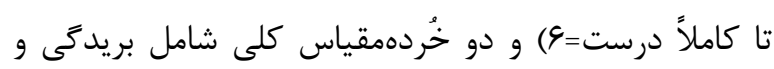

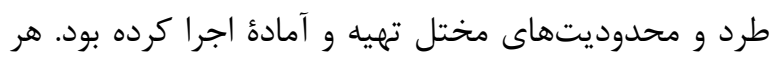

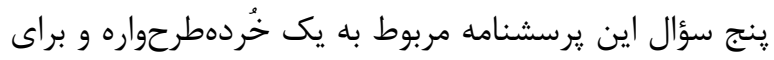

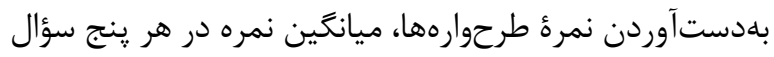

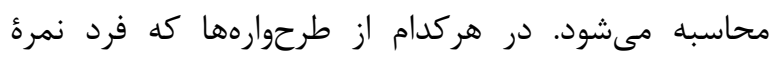

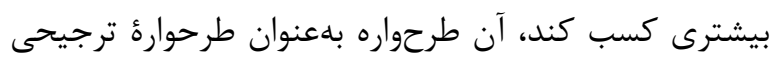

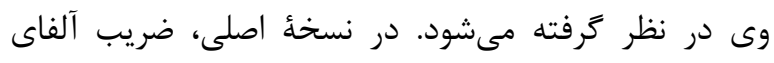

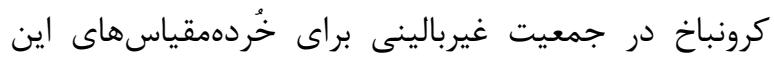

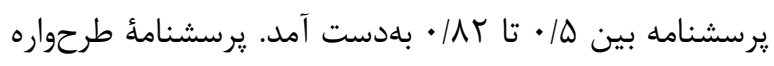

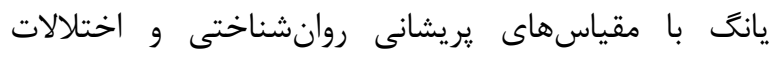

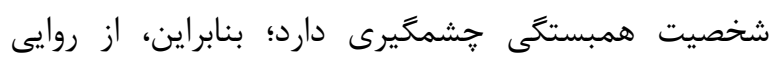

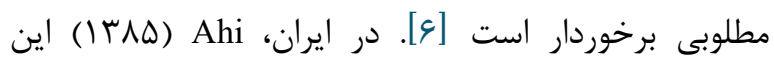

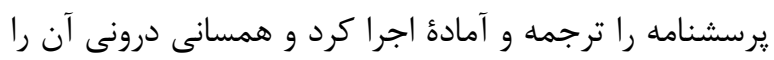

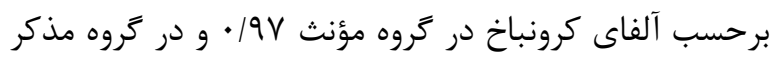

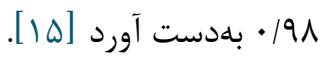


ميانكَين و انحراف استاندارد و در بُعد استنباطى از روش تحليل كوواريانس استفاده شد. افزونبراين، بهمنظور تحليل

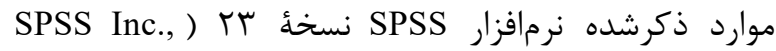

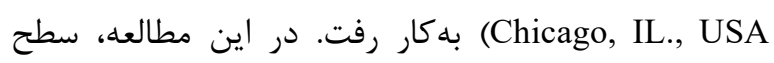

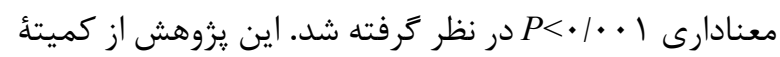

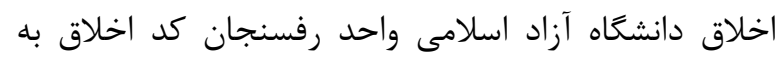

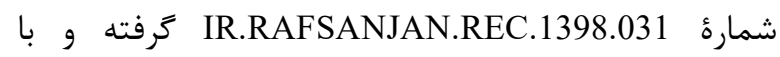
شماره

ثبت شده بود.

\section{بافته ها}

دادهها براى بررسى اثربخشى يو يادرمانى بر طرحوارههاى

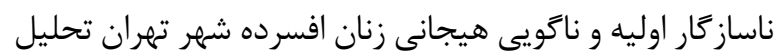

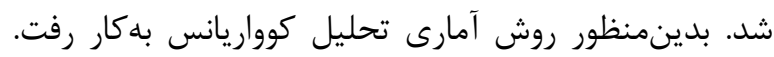

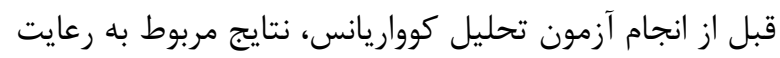

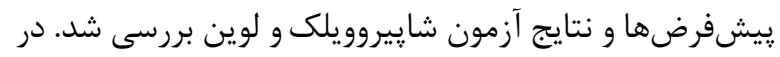

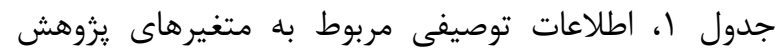
بههمراه نتايج تحليل كوواريانس ارائه شده است.
•در جلسؤ ششم گرمكردن بدن، تمرينات تمركزى شامل

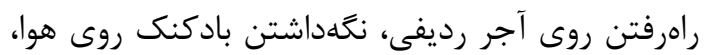

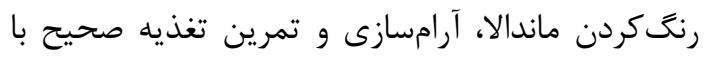
سفرة رنخين سلامت آموزش داده شد. •جلسأ هفته به ترمكردن بدن، تمرينات جلسات قبل،

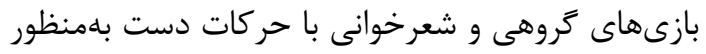
اجتماعىشدن زنان و آرامسازى تعلق كرفت. • در جلسهٔ هشتم گرمكردن بدن، آموزش حركت سلان سلام بر

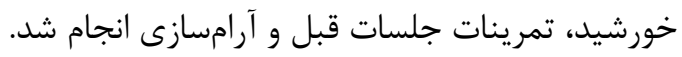

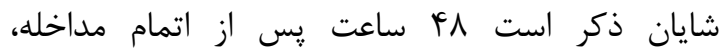

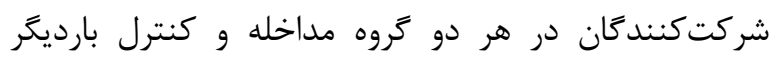
يرسشنامهها را تكميل كردند. ملاحظات اخلاقى يزوهش حرد حاضر

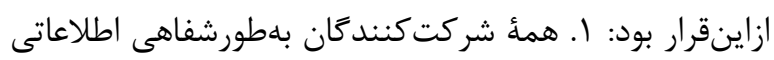
دربارئ يزوهش دريافت و درصورت تمايل مشاركت كردند؛ ז. به آزمودنىها اطمينان داده شد كه تمامى اطلاعات آنان

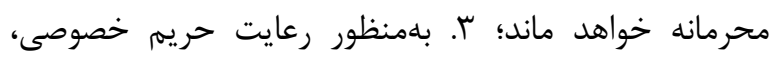

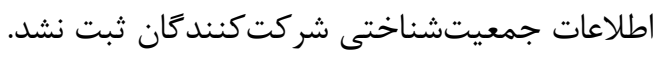
براى تجزيهوتحليل دادههاى جمعآورىشده، از روشهان نداى آمار توصيفى و استنباطى و براى توصيف دادهها، از جداول دادهاي

جدول ا. شاخصهاى توصيفى متغيرهاى يزوهش به تفكيك تروه و مر حلة آزمون

\begin{tabular}{|c|c|c|c|c|c|c|c|}
\hline \multicolumn{2}{|c|}{ آزمون لوين سطح معنادارى } & يس آزمون & ي بيش آزمون & \multirow{2}{*}{ تعداد } & \multirow{2}{*}{ تروه } & \multirow{2}{*}{ خُر دهمقياس } & \multirow{2}{*}{ متغير } \\
\hline & & Mean \pm SD & Mean \pm SD & & & & \\
\hline \multirow{4}{*}{ - IDFT } & \multirow{4}{*}{ - ITV } & $\mid Q / \Delta \cdot \pm F / T \Lambda$ & $r I / \cdot r \pm r / \Lambda \Delta$ & 10 & آزمايش & \multirow{3}{*}{ بريدگى و طرد } & \multirow{4}{*}{ طاساز } \\
\hline & & $\mid Q / \wedge r \pm \Gamma / \Gamma \wedge$ & $\mid \varepsilon / \uparrow \varepsilon \pm \Gamma / \Delta$. & 10 & كنترل & & \\
\hline & & $\mid V / V E \pm F / F r$ & $\mid r / g r \pm r / V r$ & 10 & آز & & \\
\hline & & IV/q. \pm r/V & $\mid V / \Lambda \cdot \pm r / r \cdot$ & 10 & كنترل & محدوديتهاى مختل & \\
\hline \multirow[t]{2}{*}{. } & $1 / 999$ & $r r / V r \pm \mid r / \cdot \varphi$ & $r V / \varepsilon V \pm r q / \Lambda$. & 10 & آزمايش & \multirow{2}{*}{\multicolumn{2}{|c|}{ ناكويى هيجانى ناكويى هيجانى }} \\
\hline & & ג & $\Gamma \varphi / \Delta \mid \pm \Delta r / \Lambda \varepsilon$ & 10 & كنترل & & \\
\hline
\end{tabular}

كه ميانگين نمرات طرحوارههاى ناسازگًار اوليه و ناگويى

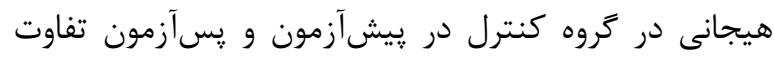
نداشت. براى بررسى طبيعىبودن توزيع دادهها از آزمون

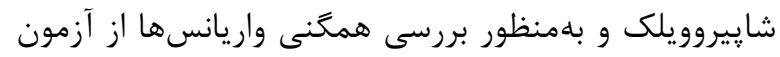

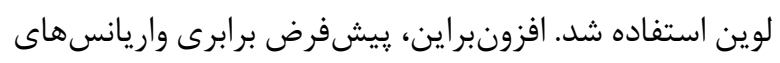

طبق نتايج مندرج در جدول ا، در پيشآزمون نمرات

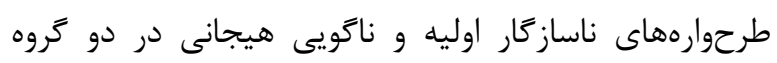
تفاوت جندانى نداشت. همجنين در گروه آزمايش، در

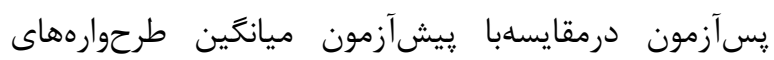
ناساز گار اوليه و ناگويى هيجانى كاهش يافت. اين در حالى بود 
يس، مىتوان از اين آزمون براى تحليل دادهها استفاده كرد. در جدول r، اين نتايج آورده شده است.

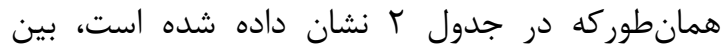
ميانگين نمرات طرحوارههاى ناساز

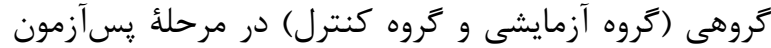
تفاوت معنادارى وجود داشت (P)

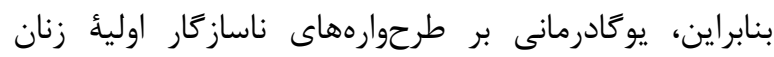

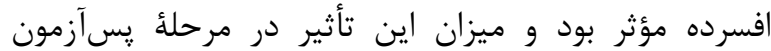

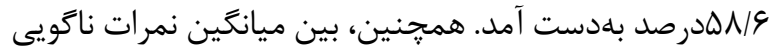
هيجانى برحسب عضويت گروهى (كروه آزمايشى و كروه كنترل) در مرحلة پِّآزمون تفاوت معنادارى وجود داشت

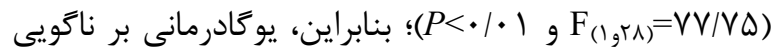

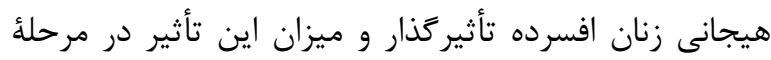

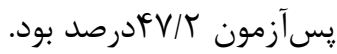

نمرات در دو گروه آزمايش و كنترل در مرحلة پِّآزمون، براى مؤلفههاى طرحوارههاى ناساز گار اوليه و ناكويى هيجانى

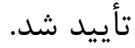

قبل از اجراى تحليل كوواريانس، بايد ييشفرضهاى انجام كوواريانس را رعايت كرد. يكى از نكاتى كه قبل از تحليل كوواريانس بايد بررسى كرد، وجود همخنى ركرسيون است.

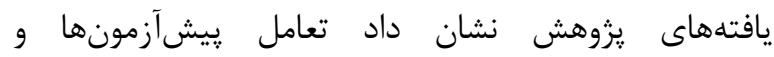
يسآزمونهاى مؤلفههاى طرحوارههاى ناسازگًار اوليه

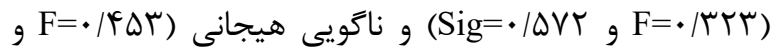

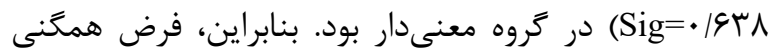

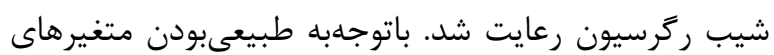
يزوهش و همخنى شيب ركرسيون و يكسانى واريانس، مفروضههاى آزمون تحليل كوواريانس يك متغيرى رعايت شد؛

جدول r. كوواريانس براى بررسى تأثير عضويت تروهى بر ميزان نمرات طرحوارههاى ناساز كار اوليه و ناكويى هيجانى

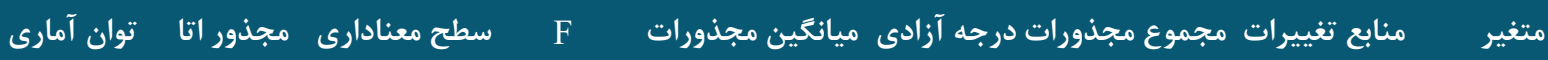

\begin{tabular}{|c|c|c|c|c|c|c|c|c|}
\hline $1 / \cdots$ & $\cdot \mid \Delta \wedge \varphi$ &.$/ \cdot 1$ & $\Delta 9 / 9 \Delta$ & $\Delta \Lambda \Lambda r / I V F$ & 1 & $\Delta \Lambda \Lambda r / I V F$ & يِيشآزمون & \multirow{3}{*}{ ناساز كار اوليه } \\
\hline- & - & - & - & $91 / 919$ & rA & 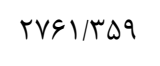 & خطا & \\
\hline- & - & - & - & - & rq & זrq/עrזו & كل اصلاحشده & \\
\hline $1 / \cdots$ & . IFVT & $\cdot 1 \cdot \cdot 1$ & $V V / V \Delta$ & TYGV/THG & 1 & MFGV/TMG & پيش آزمون & \multirow{3}{*}{ ناكويى هيجانى } \\
\hline- & - & - & - & $F F / \Delta q 1$ & rA & ITFN/GIT & خطا & \\
\hline- & - & - & - & - & rq & $V F \mid \varepsilon / r \Delta V$ & كل اصلاحشده & \\
\hline
\end{tabular}

تكنيكهاى يوگا در تغيير نخرش و تفكر و طرحوارههاى

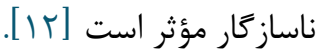
در تبيين يافتهٔ مذكور، مىتوان كفت كه تمرينات يوكا از مونر المان

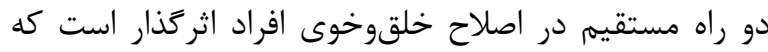
يكى از آنها رهاشدن آندروفينها (ايجادكننده احساسات خوشايند) و ديخرى كاهش سطح كورتيزول (هورمون ترشحشده در خون با فشار عصبى) است. همانگونه كه مىدانيم، آندروفينها داروى طبيعى كاهش درد درن هستند و تمرينات بدنى با اثر افزايشدهندهاى در سطوح آندروفين، سبب بلوجودآمدن احساسات خوشايند مىشوند. ازآنجاكه
نتايج حاصل از آزمون فرضيههاى تحقيق نشان داد كه

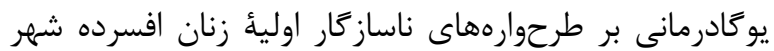
تهران مؤثر بود. اين يافته با يزوهش Ghanbari Hashem Abadi دادند حركات ريتميك يوگا بر تعاملات اجتماعى زنان

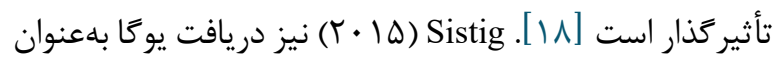
درمان كمكى مىتواند به بيماران با مشكلات و تجارب

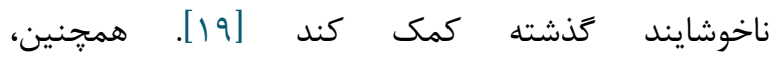
Balasubramaniam 
در تبيين نتايج تحقيق حاضر، مىتوان كفت يوكا شامل وضعيتهاى بدنى و تكنيكهاى تنفسى و مراقبه است كه بدن

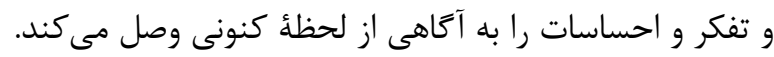

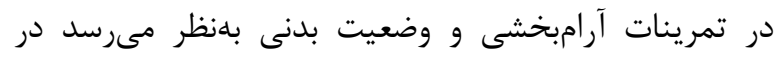
آموزش يوكا به زنان كه مراحل كوناتونى را كنارهم تمرين مى كنند، باعث مىشود كه زنان حين فعاليت برنامهٔ منظمه

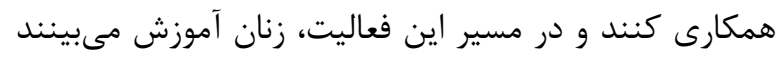

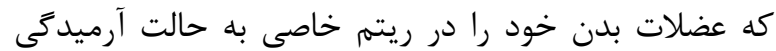

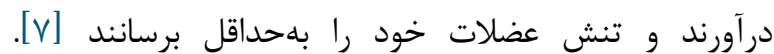

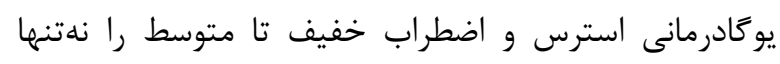

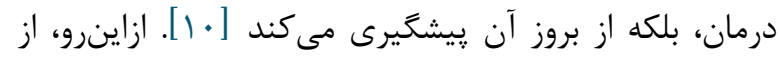
ديخر دلايل تأثير كذارى كه مىتواند به ناتويى هيجانى افراد حاضر در اين كلاسها منجر شود، مىتوان به ماهيت يوكا،

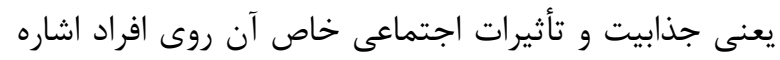
كرد كه با ارتقاى روابط مثبت فرد با ديكران و ايجاد احساس خداس

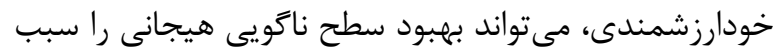

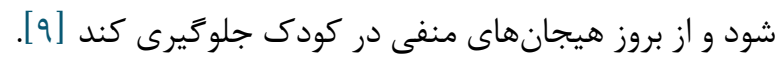

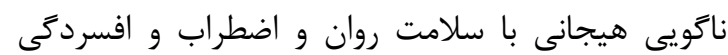
ارتباط دارد و اين اختلال عاملى خطرساز براى بسيارى از

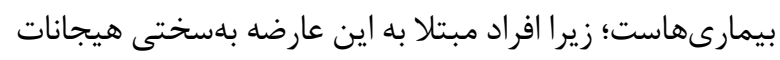

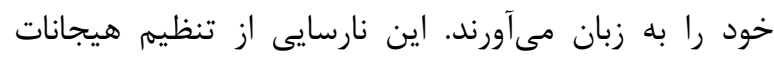
جلوگيرى و ساز كارى موفقيتآميز را مشكل مى كند. درواقع، افرادى كه مىتوانند بهموقع هيجانهاى خود ران را بروز دهند، از

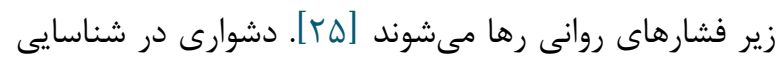

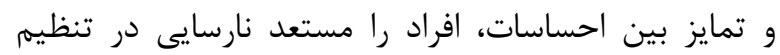

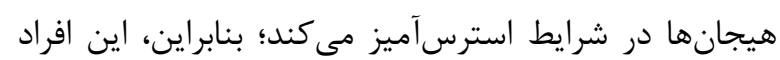

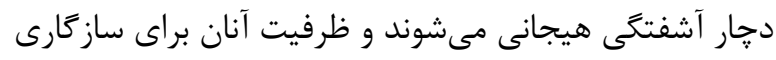

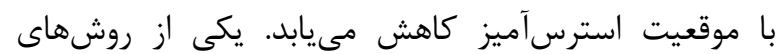

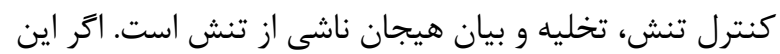

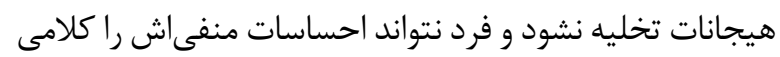
بيان كند، جزء روانشناختى سيستمهاى ابراز هيجان، ازجمله فئه افسردىى و اضطراب افزايش مى يابد. افرادى كه قابليت شناخت

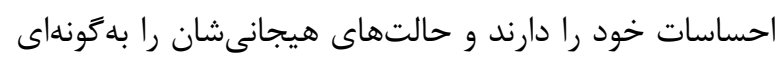

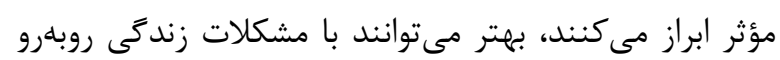

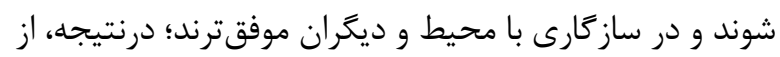

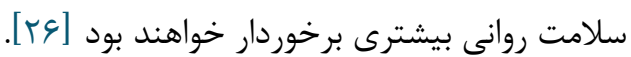

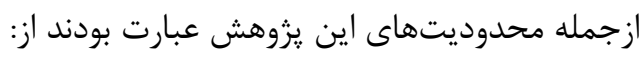

يكى از عوامل مؤثر بر شادى، سلامت جسمانى است، توانايى مبارزه با بيمارىها و برقراركردن تعادل هورمونى و كنترل

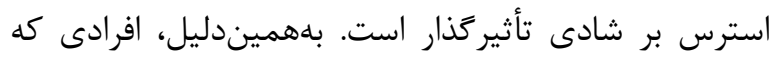
ورزش مى كنند، مىتوانند شادتر باشند. ورزش باعث تحريك آند توليد يروتئينهايى مىشود كه به آنها آنتىبادى كفتها مىشود و با بيمارىها مبارزه مى كنند؛ بنابراين، افرادى كه

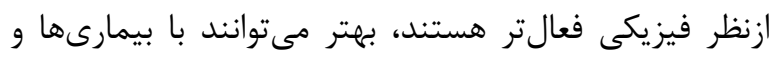
استرس مبارزه كنند و اين امر باعث شادى بيشتر آنان مىشودي

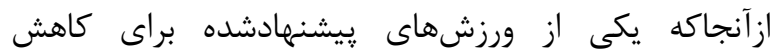

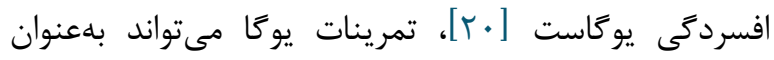
محركى قوى براى سيستمهاى هييوتالاموسى، هييوفيزى، آدرنالى و نور آدرنرزيك عمل كند واي سيست و با كاهش كورتيزول و

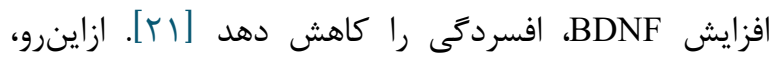

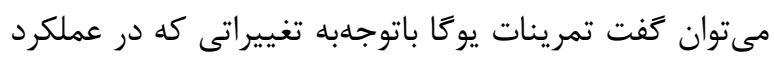
فيزيولوزيكى، فعلوانفعالات شيميايى، سلولهاى مغز سيستم ايمنى بدن ايجاد مى كنند، سريعتر و بيشتر مى توانند

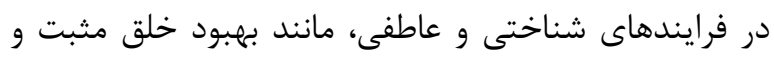
سطح طرحوارههاى ناساز كار اوليئ افراد تغيير ايجاد كنند.

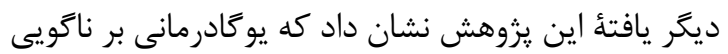

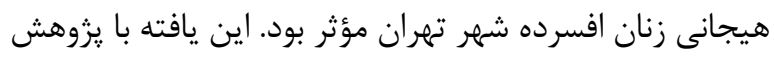
Streeter

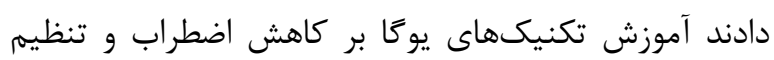

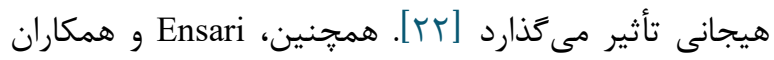

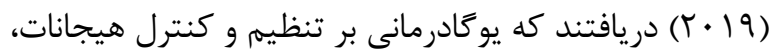
ازجمله افسردىى و اضطراب اثركذار است [بr]. Harvey و

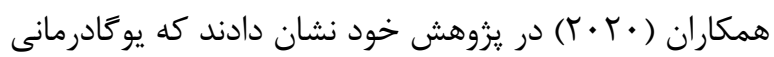
مىتواند فشارهاى روانى را در افراد افسرده و مضطرب كاهش

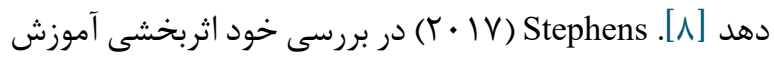
يوكا در كاهش اختلال ناكويى هيجانى و بروزنيافتن احساسات

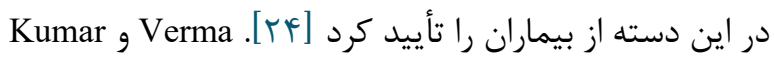
(ع • (T) در بررسى خود نشان دادند آموزش يوكا و ايجاد تمركز

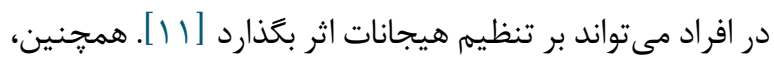
Balasubramaniam

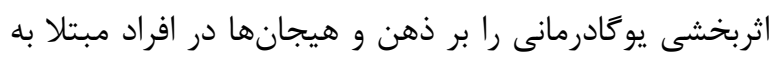

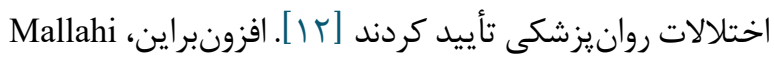

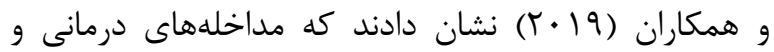

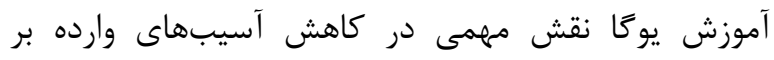

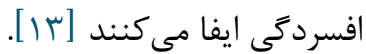




\section{نتيجه گيبرى}

نتايج اين يزوهش نشان داد كه يوگادرمانى موجب كاهش

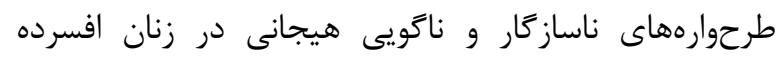
مىشود. اين يافتهها مىتواند كام مفيدى براى حل مشكلات زنان افسرده و درنهايت، تضمين سلامت جسمى و روانى آنان

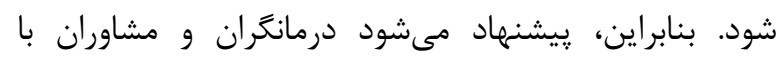
شناسايى طرحوارههاى ناساز گار اوليه و ناگويى هاى هيجانى و

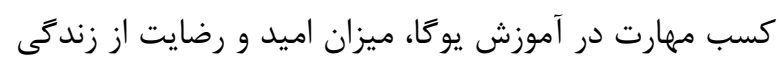

$$
\text { رادر زنان افسرده افزايش دهند. }
$$

\section{سياسگز ارى}

اين مقاله از يايان نامةٔ كارشناسى ارشد رشتأ روانشناسى

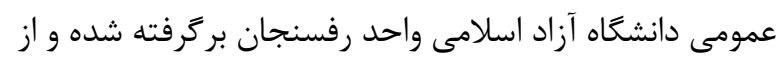

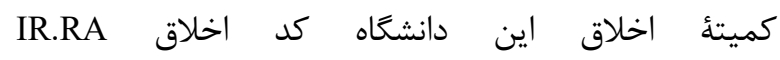
FSANJAN.REC.1398.031 دريافت كرده است. نويسند آنان از تمامى مسئولان دانشعاه و شركت كنند

$$
\text { تشكر مى كنند. }
$$

$$
\text { سهم نويسند }
$$

سحر سعيدى اصل: نغارش اولئٌ مقاله و تهيئ پِيشنويس

$$
\text { اولئٔ مقاله را برعهده داشت. سيدي: ناهرت }
$$

فاطمه السادات رباطلى: بخش تجزيهوتحليل آمارى دادهها و نظارت بر اجراى يزوهش را برعهده داشت. بحت لجرئ.

$$
\text { تعارض در منافع }
$$

بين نويسندَان هيجَّونه تعارضى در منافع وجود ندارد

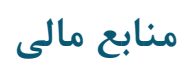

منابع مالى اين مطالعه توسط نويسندكان تامين شده است.

\section{References}

1. Naveen GH, Varambally S, Thirthalli J, Rao M, Christopher R, Gangadhar BN. Serum cortisol and BDNF in patients with major depression- effect of yoga. Int Rev Psychiatry. 2016; 28(3): 273-78. [DOI:10.1080/09540261.2016.1175419] [PMID]
• نتايج مطالعه به زنان افسرده شهر تهران محدود بود؛ ازاينرو درصورت نياز به تعميم به ساير محدودههاى سنى، اين كار با احتياط و دانش كافى بايد انجام شود.

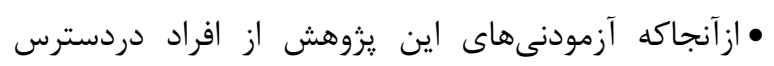

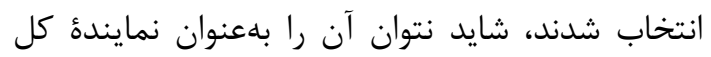

$$
\text { جامعه در نظر كرفت. }
$$

• بهدليل محدوديتهاى زمانى محقق و دسترسىنداشتن،

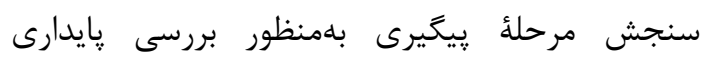

$$
\text { تغييرات بلوجودآمده ميسر نشد. }
$$

• در اين يزوهش، از ابزار يرسشنامه استفاده شد؛ درنتيجه،

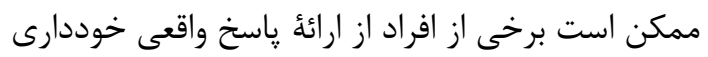
كرده يا با بىدقتى و كمتوجهى گياسخ داده باشند.

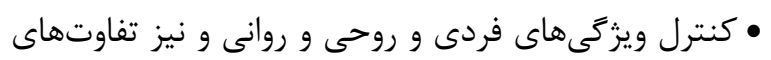

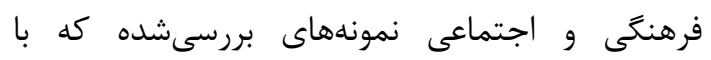
ياسخ گويى به يرسشها بر نتايج يروهش تأثير گذار بودند،

$$
\text { از عهده يزوهشخر خارج بود. }
$$

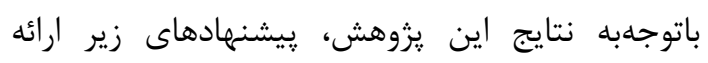
مىشود: • براى افزايش طرحوارههاى ناساز گار اولئُ يايدار زنان با انجام

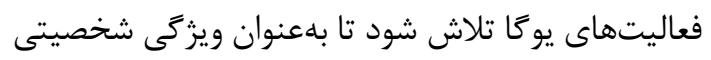

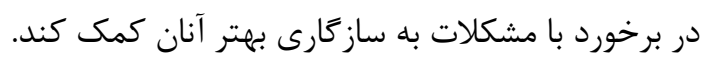
• براى يرورش عواطف مثبت و تنظيم هيجانات زنان، به يورًا بهعنوان فعاليتى ورزشى زنان بها داده شود. باتوجهبه

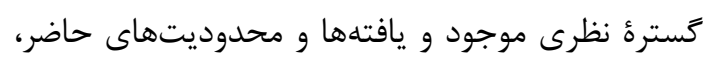

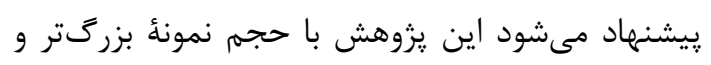

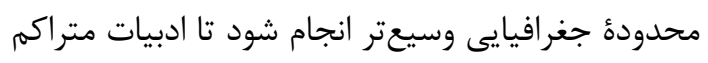

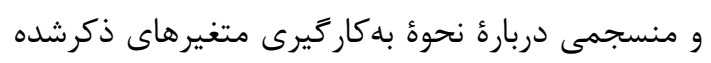

$$
\text { فراهم آيد. }
$$

•از ساير روشهاى مداخلهاى كه اثربخشى آنان بر بهبود طرحوارههاى ناساز گار اوليه و ناگويى هيجانى زنان تأييد شده است، بلصورت مقايسهاى با ورزش يوكا استفاده شود.

2. Dumas JE, Neese DE, Prinz RJ, Blechman EA. Shortterm stability of aggression, peer rejection, and depressive symptoms in middle childhood. J Abnorm $\begin{array}{lll}\text { Child } & \text { Psychol. 2017; } & \end{array}$ [DOI:10.1007/BF01448376] [PMID] 
3. Pozza A, Albert U, Dèttore D. Early maladaptive schemas as common and specific predictors of skin picking subtypes. BMC Psychol. 2020; 8(1):27. [DOI:10.1186/s40359-020-0392-y] [PMID] [PMCID]

4. Aloi M, Rania M, Caroleo M, Carbone EA, Fazia G, Calabrò $\mathrm{G}$, et al. How are early maladaptive schemas and DSM-5 personality traits associated with the severity of binge eating? J Clin Psychol. 2020; 76(3): 539-48. [DOI:10.1002/jclp.22900] [PMID]

5. Gojani PJ, Masjedi M, Khaleghipour S, Behzadi E. Effects of the schema therapy and mindfulness on the maladaptive schemas hold by the psoriasis patients with the psychopathology symptoms. Adv Biomed Res. 2016; 6(1): 54-62. [DOI:10.4103/2277-9175.190988] [PMID] [PMCID]

6. Young JE. Young Schema Questionnaire- Short Form. New York: Schema Therapy Institute; 2008.

7. Yousefi R, Seyed Hashemi SG, Sohrabi L, Hossein Abadi M. The association between early maladaptive schemas and defense styles with hoarding behaviour among university students. Pract Clin Psychol. 2018; 6(4): 223-30. [DOI:10.32598/jpcp.6.4.223]

8. Harvey R, Andriopoulou P, Grogan S. Perceived mechanisms of change in therapeutic yoga targeting psychological distress. J Bodyw Move Ther. 2020; 24(1): 274-80. [DOI:10.1016/j.jbmt.2019.06.014] [PMID]

9. Ruiz-Aranda D, Salguero JM, Fernandez-Berrocal P. Emotional regulation and acute pain perception in women. J Pain. 2009; 11(6): 564-69. [DOI:10.1016/j.jpain.2009.09.011] [PMID]

10. Den Heijer AE, Groen Y, Tucha L, Fuermaier A.B, Koerts J, Lange KW, et al. Sweat it out? The effects of physical exercise on cognition and behavior in children and adults with ADHD: A systematic literature review. J Neural Transm. 2017; 124(Suppl 1): 3-26. [DOI:10.1007/s00702-016-1593-7] [PMID] [PMCID]

11. Verma S, Kumar K. Evidence based study on super brain yoga and its application on alpha EEG in adolescence. Int J Sci Conscious. 2016; 2(4): 40-46.

12. Balasubramaniam M, Telles S, Doraiswamy PM. Yoga on our minds: A systematic review of yoga for neuropsychiatric disorders. Front Psychiatry. 2013; 3: 117. [DOI:10.3389/fpsyt.2012.00117] [PMID] [PMCID]

13. Mallahi K, Ghodrati S, Vatankhah H. Effectiveness of gestalt group play therapy to aggression and social skills of children sexual abused in the child labors group. J Pediatric Nurs. 2019; 6(1): 54-63.

14. Taherdoost H. Sampling methods in research methodology; How to choose a sampling technique for research. SSRN Elect J. 2016; 5(2): 18-27. [DOI:10.2139/ssrn.3205035]

15. Ahi Gh, Mohammadifar MA, Besharat MA. Reliability and validity of Young schema Questionnaire-Short Form. J Psychol Educ. 2007; 37(3): 5-20.

16. Karreman A, Vingerhoest AdJ. Attachment and wellbeing: The mediating role of emotion regulation and resilience. Pers Individ Differ. 2012; 53(7): 821-826. [DOI:10.1016/j.paid.2012.06.014]

17. Hosseini F, Khayyer M. The role of teacher in mathematical academic emotional and emotional regulation students. J Psychol. 2011; 5(20): 41-63.

18. Ghanbari Hashem Abadi BA, Saadat M. The effect of yoga rhythmic movements on the social interactions of children with mental deficiency. Stud Educ Psychol. 2010; 11(1): 171-88.

19. Sistig B. Mindful yoga as an adjunct treatment for forensic inpatients: A preliminary evaluation. J Forensic Psychiatry Psychol. 2015; 26(6): 824-46. [DOI:10.1080/14789949.2015.1062996]

20. Danucalov M, Simoes RS, Kozasa EH, Leite JA. Cardiorespiratory and Metabolic Changes during Yoga Sessions. Appl Psychophysiol Biofeedback. 2008; 33(2): 77-81. [DOI:10.1007/s10484-008-9053-2] [PMID]

21. Naveen GH, Varambally S, Thirthalli J, Rao M, Christopher R, Gangadhar BN. Serum cortisol and BDNF in patients with major depression-effect of yoga. Int Rev Psychiatry. 2016; 28(3): 273-78. [DOI:10.1080/09540261.2016.1175419] [PMID]

22. Streeter CC, Whitfield TH, Owen L, Rein T, Karri SK, Yakhkind A, et al. Effects of yoga versus walking on mood, anxiety, and brain GABA levels: A randomized controlled MRS study. J Altern Complement Med. 2010; 16(11): 1145-52. [DOI:10.1089/acm.2010.0007] [PMID] [PMCID]

23. Ensari I, Petruzzello SJ, Motl RW. The effects of acute yoga on anxiety symptoms in response to a carbon dioxide inhalation task in women. Complement Ther $\begin{array}{lll}\text { Med. 2019; } & \text { 3(5): }\end{array}$ [DOI:10.1016/j.ctim.2019.102230] [PMID]

24. Stephens I. Medical yoga therapy. Children. 2017; 4(2):12. [DOI:10.3390/children4020012] [PMID] [PMCID]

25. Rezaei F, Karimi F, Afshari A, Hosseini-Ramaghani N. The correlation between alexithymia and anxiety, depression in asthma. Feyz (J Kashan Uni Med Sci). 2017; 21(2): 179-87.

26. Korostiy V. Alexithymia, aggressiveness and predictive ability in patients with psychosomatic diseases and emotional (anxiety and depressive) disorders. Eur Psychiatry. 2015; 30(2): 1251. [DOI:10.1016/S09249338(15)32006-X]

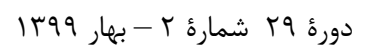

